\title{
Structure and functioning of the acid-base system in the Baltic Sea
}

\author{
Karol Kuliński $^{1}$, Bernd Schneider ${ }^{2}$, Beata Szymczycha ${ }^{1}$, and Marcin Stokowski ${ }^{1}$ \\ ${ }^{1}$ Institute of Oceanology, Polish Academy of Sciences, IO PAN, \\ ul. Powstańców Warszawy 55, 81-712 Sopot, Poland \\ ${ }^{2}$ Leibniz Institute for Baltic Sea Research Warnemünde, IOW, Seestrasse 15, 18119 Rostock, Germany \\ Correspondence: Karol Kuliński (kroll@iopan.gda.pl)
}

Received: 6 April 2017 - Discussion started: 12 April 2017

Revised: 21 October 2017 - Accepted: 6 November 2017 - Published: 11 December 2017

\begin{abstract}
The marine acid-base system is relatively well understood for oceanic waters. Its structure and functioning is less obvious for the coastal and shelf seas due to a number of regionally specific anomalies. In this review article we collect and integrate existing knowledge of the acid-base system in the Baltic Sea. Hydrographical and biogeochemical characteristics of the Baltic Sea, as manifested in horizontal and vertical salinity gradients, permanent stratification of the water column, eutrophication, high organic-matter concentrations and high anthropogenic pressure, make the acid-base system complex. In this study, we summarize the general knowledge of the marine acid-base system as well as describe the peculiarities identified and reported for the Baltic Sea specifically. In this context we discuss issues such as dissociation constants in brackish water, different chemical alkalinity models including contributions by organic acid-base systems, long-term changes in total alkalinity, anomalies of borate alkalinity, and the acid-base effects of biomass production and mineralization. Finally, we identify research gaps and specify limitations concerning the Baltic Sea acid-base system.
\end{abstract}

\section{Introduction}

The acid-base system controlling seawater $\mathrm{pH}$ is formed by a number of chemical substances having acid-base properties (Dickson et al., 2007). The importance of each of these substances (structure of the acid-base system) depends on both concentrations of individual constituents and their dissociation constants. The control by physical conditions (temperature, salinity) and biogeochemical processes (e.g. biomass production and mineralization) as well as interrelationships between individual components determine the functioning of the acid-base system. The understanding of the structure and functioning of the acid-base system is necessary to investigate important issues that shape the Baltic Sea ecosystem and that are of interest in present-day chemical oceanography, such as ocean acidification, calcium carbonate $\left(\mathrm{CaCO}_{3}\right)$ formation/dissolution and carbon dioxide $\left(\mathrm{CO}_{2}\right)$ exchange through the air-sea interface.

The steady increase in atmospheric $\mathrm{CO}_{2}$ concentrations leads to enhanced dissolution of $\mathrm{CO}_{2}$ in the ocean. Since
$\mathrm{CO}_{2}$ dissolved in seawater forms diprotic carbonic acid, hydrogen ions are released. Although the major fraction of the hydrogen ions are taken up by carbonate ions (a buffering reaction), a significant fraction stays in the water column and thus causes a decrease in $\mathrm{pH}$. This phenomenon is known in the scientific literature as "ocean acidification" although seawater does not really become acidic but only moves from its alkaline character towards the acidic regime (Riebesell et al., 2010). Ocean acidification has been recognized as one of the greatest threats for marine ecosystems not only by the scientific community (e.g. Bates et al., 2014; Zeebe, 2012), but also in European Union (EU) legislation. The EU Marine Strategy Framework Directive (MSFD, 2008) explicitly points out that the EU member states should place more attention on ocean acidification and emphasizes the necessity to include measurements of $\mathrm{pH}$ and of the $\mathrm{CO}_{2}$ partial pressure $\left(\mathrm{pCO}_{2}\right)$ as descriptors for the environmental status of marine regions. 
There is a general belief that the magnitude of ocean acidification can be sufficiently quantified from the atmospheric $\mathrm{pCO}_{2}$ levels and the $\mathrm{CO}_{2}$ exchange between seawater and the atmosphere (Zeebe, 2012; Riebesell et al., 2010; Caldeira and Wicket, 2003). This is generally true for oceanic waters. However, it is not the case for coastal seas because several other processes influence seawater $\mathrm{pH}$ such as $\mathrm{CaCO}_{3}$ formation and/or dissolution, eutrophication or oligotrophication, total alkalinity $\left(A_{\mathrm{T}}\right)$ consumption and production, weathering, contribution by organic substances, and terrestrial inputs. The general structure and functioning of the acid-base system in seawater are relatively well identified; however, some aspects still show a lot of gaps and/or shortcomings, which can lead to wrong conclusions and questionable predictions of the future pH development (Orr et al., 2015; Koeve and Oschlies, 2012; Hunt et al., 2011; Dickson et al., 2007; Cai et al., 1998).

Since the $\mathrm{CO}_{2}$ system is an integral part of the ocean acidbase system, it is impossible to understand the $\mathrm{CO}_{2}$ system and to assess processes such as the $\mathrm{CO}_{2}$ gas exchange or $\mathrm{CaCO}_{3}$ dissolution/formation without a clear idea about the structure and functioning of the whole acid-base system. The saturation states of calcite and aragonite are of crucial importance for organisms forming their exoskeletons from $\mathrm{CaCO}_{3}$. Although pelagic calcifying organisms do not occur in the Baltic Sea, this aspect is still relevant as some benthic organisms can also build $\mathrm{CaCO}_{3}$ into their shells (Tyrrell et al., 2008). Moreover, calcifying processes not only depend on the acid-base system structure but in turn can modify it by decreasing the concentration of carbonate ions $\left(\mathrm{CO}_{3}^{2-}\right)$ and thus the alkalinity.

Carbon dioxide is a major component of the global carbon cycle and transport of $\mathrm{CO}_{2}$ links all Earth's compartments. It is believed that the world oceans absorb about $25 \%$ of anthropogenic $\mathrm{CO}_{2}$ emissions. However, there is still a debate on the role that the shelf seas play in this context (Le Quéré, 2016). The direction and magnitude of the $\mathrm{CO}_{2}$ exchange through the air-sea interface depend largely on the $\mathrm{pCO}_{2}$ difference between seawater and the atmosphere. The level of seawater $\mathrm{pCO}_{2}$ is mainly controlled by the structure of the acid-base system, which is influenced by the combined effect of biological activity (biomass production vs. mineralization), $\mathrm{CO}_{2}$ exchange with the atmosphere and temperature (Emerson and Hedges, 2008).

In this context the Baltic Sea can be considered a very complex ecosystem. On the one hand, the low buffer capacity (Beldowski et al., 2010) makes the seawater vulnerable to acidification in most regions of the Baltic Sea; on the other hand, the sea is exposed to various anthropogenic influences which have the potential to change the acid-base system and thus also seawater $\mathrm{pH}$ and all $\mathrm{pH}$-related processes. This makes the Baltic Sea different from the oceans for which the $\mathrm{CO}_{2}$ system as part of the acid-base system has been well characterized during the last decades (Bates et al., 2014; Riebesell et al., 2010; Dickson et al., 2007). A considerable research effort was also made in recent years to investigate the Baltic Sea $\mathrm{CO}_{2}$ system and its peculiarities. However, this was done from different perspectives and resulted in specific problem-oriented and diverse knowledge. Therefore, the goal of this review article is to collect and integrate the existing knowledge of the structure and functioning of the acid-base system in the Baltic Sea, to point out the research gaps and thus also to address challenges for the future research in this field.

\section{The standard acid-base model for ocean water}

Four measurable variables exist to describe the acid-base system of seawater. These are $\mathrm{pCO}_{2}, \mathrm{pH}$, total inorganic carbon concentration $\left(C_{\mathrm{T}}\right.$, known also as DIC) and total alkalinity $\left(A_{\mathrm{T}}\right) . C_{\mathrm{T}}$ is the total concentration of all inorganic carbon forms present in seawater (Eq. 1), where $\left[\mathrm{CO}_{2} *\right]$ represents the sum of molecular dissolved $\mathrm{CO}_{2}$ and undissociated carbonic acid $\left(\mathrm{H}_{2} \mathrm{CO}_{3}\right)$ :

$$
C_{\mathrm{T}}=\left[\mathrm{CO}_{2}^{*}\right]+\left[\mathrm{HCO}_{3}^{-}\right]+\left[\mathrm{CO}_{3}^{2-}\right] \text {. }
$$

Measurements of $C_{\mathrm{T}}$ are usually based on the acidification of the sample and coulometric or infrared detection of the extracted $\mathrm{CO}_{2}$ (Dickson et al., 2007). $A_{\mathrm{T}}$ is defined as the excess of proton acceptors (bases formed from weak acids with a dissociation constant of $K \leq 10^{-4.5}$ at $25^{\circ} \mathrm{C}$ ) over proton donors (acids with $K>10^{-4.5}$ ) and expressed as the hydrogen ion equivalent in $1 \mathrm{~kg}$ of sample (Dickson, 1981):

$$
\begin{aligned}
A_{\mathrm{T}} & =\left[\mathrm{HCO}_{3}^{-}\right]+2\left[\mathrm{CO}_{3}^{2-}\right]+\left[\mathrm{B}(\mathrm{OH})_{4}^{-}\right]+\left[\mathrm{OH}^{-}\right] \\
& +\left[\mathrm{HPO}_{4}^{2-}\right]+2\left[\mathrm{PO}_{4}^{3-}\right]+\left[\mathrm{SiO}(\mathrm{OH})_{3}^{-}\right]+\left[\mathrm{NH}_{3}\right] \\
& +\left[\mathrm{HS}^{-}\right]+[\text {minor bases }]-\left[\mathrm{H}^{+}\right]-\left[\mathrm{HSO}_{4}^{-}\right]-[\mathrm{HF}] \\
& -\left[\mathrm{H}_{3} \mathrm{PO}_{4}\right]-[\text { minor acids }] .
\end{aligned}
$$

$A_{\mathrm{T}}$ can be determined by open- or closed-cell acidimetric titration. For both $C_{\mathrm{T}}$ and $A_{\mathrm{T}}$ certified reference materials are provided by Andrew Dickson's laboratory, UC San Diego, USA (Dickson et al., 2007). pH measurements in seawater are usually calibrated against tris buffer. Its characteristics are well known at salinities of 20-35 (Mosley et al., 2004; DelValls and Dickson, 1998). The efforts to improve the tris buffer characteristics for lower salinities are ongoing within the BONUS PINBAL project (https:// www.io-warnemuende.de/pinbal-home.html). The use of tris buffer helps to calibrate the systems for $\mathrm{pH}$ measurements but does not fully guarantee the quality of the $\mathrm{pH}$ results as reference materials in seawater matrix still do not exist for $\mathrm{pH}$ measurements. In many cases $\mathrm{pH}$ is still measured potentiometrically on the NBS scale although spectrophotometric measurements on the total scale $\left(\mathrm{pH}_{\text {tot }}\right)$, which also takes into account $\mathrm{HSO}_{4}^{-}$ions, are currently state of the art in the field of chemical oceanography. The concentration of $\mathrm{CO}_{2}^{*}$ in seawater is obtained from the partial pressure of $\mathrm{CO}_{2}$ in air in 
equilibrium with seawater. According to the standard operating procedure (Dickson et al., 2007), measurements of $\mathrm{pCO}_{2}$ require the continuous flow of water, which makes this parameter difficult to measure in discrete samples.

All four variables interact and control the $\mathrm{pH}$ as described by a set of equilibrium constants and mass balance equations. In general the interrelationships between these four parameters facilitate the calculation of any two variables when the two others are known, e.g. through measurements, and when the dissociation constants of the involved acid-base reactions are known for the respective temperature and salinity. This fact is used in biogeochemical models for simulations of the marine $\mathrm{CO}_{2}$ system. All biogeochemical models are based on the transport and transformations of $A_{\mathrm{T}}$ and $C_{\mathrm{T}}$ because these variables are independent of temperature and pressure and behave conservatively with respect to mixing (mass conservation). Moreover, straightforward techniques for sampling and analysis for $A_{\mathrm{T}}$ and $C_{\mathrm{T}}$ exist and are supported by the availability of reference materials (Dickson et al., 2007). Hence, these two variables are very well suited for $\mathrm{CO}_{2}$ system studies. However, the use of $A_{\mathrm{T}}$ and $C_{\mathrm{T}}$ for the $\mathrm{CO}_{2}$ system studies is not free of limitations. To obtain high accuracy for the calculation of $\mathrm{pH}$ and $\mathrm{pCO}_{2}$ from measured or modelled $A_{\mathrm{T}}$ and $C_{\mathrm{T}}$, all dissociation constants and total concentrations of all non- $\mathrm{CO}_{2}$ components of the acid-base system must be known. This requirement is generally fulfilled with regard to ocean studies where the total concentrations of non- $\mathrm{CO}_{2}$ acid-base components are either negligible or can be approximated as a function of salinity (Riebesell et al., 2010). However, this issue is more critical for coastal and shelf regions, where the biogeochemical composition of seawater shows regional peculiarities (e.g. Kuliński 2014; Hernandez-Ayon et al., 2007; Cai et al., 1998). This is the case for the Baltic Sea, which shows various unique biogeochemical characteristics.

\section{Peculiarities of the Baltic Sea acid-base system}

\subsection{Hydrographic setting}

The Baltic Sea is one of the largest brackish ecosystems in the world. This is caused by both limited inflows of saline oceanic water through the shallow and narrow Danish Straits and high river runoff. The drainage basin of the Baltic Sea is almost 4 times larger than the area of the sea itself, while the mean annual freshwater supply $\left(428 \mathrm{~km}^{3}\right)$ constitutes about $2 \%$ of the Baltic Sea water volume $\left(22 \times 10^{3} \mathrm{~km}^{3}\right)$. The specific features of the Baltic Sea hydrology cause clear horizontal and vertical salinity gradients. Salinity in the surface layer fluctuate from 2 in the northern Bothnian Bay to $>20$ observed in the Kattegat. Dense and highly saline water, which irregularly enters the Baltic Sea, sinks and moves along the sea bottom. This deep water is separated from the brackish surface water layer by a permanent halocline located at a depth of $60-70 \mathrm{~m}$, which is at the same time the maximum mixed layer depth in the Baltic Sea (Lass and Matthäus, 2008; Winsor et al., 2001). The stratification limits ventilation of the deep-water masses. Simultaneously, the deeper water layers are supplied with large amounts of particulate organic matter that either originated from terrestrial sources or derived from the biomass production in the surface under the influence of high nutrient concentrations (eutrophication). Some fraction of the sedimentary organic matter mineralizes releasing $\mathrm{CO}_{2}$ and consuming oxidants, which leads to hypoxia or even anoxia in the bottom waters (HELCOM, 2009).

\subsection{Dissociation constants in brackish water}

If any variables of the marine $\mathrm{CO}_{2}$ system are to be used for biogeochemical studies, it is advisable to measure these directly and not to derive it from the measurements of other variables of the $\mathrm{CO}_{2}$ system (Dickson et al., 2007). However, sometimes direct measurements may be prevented by technical reasons or routine analytical methods do not exist. The latter refers, for example, to the determination of $\mathrm{CO}_{3}^{2-}$ ion concentrations, which are important for the assessment of the state of the $\mathrm{CaCO}_{3}$ saturation and thus for the dissolution or formation of $\mathrm{CaCO}_{3}$ shells. In this case, calculations on the basis of other known variables such as $C_{\mathrm{T}}, A_{\mathrm{T}}$, $\mathrm{pCO}_{2}$ or $\mathrm{pH}$ are indispensable and require knowledge about the equilibrium constants of the $\mathrm{CO}_{2}$ system. Here we examine the availability of the necessary constants for low-salinity brackish water. Three fundamental equations characterize the equilibria of the marine $\mathrm{CO}_{2}$ system. The first refers to the solubility of gaseous $\mathrm{CO}_{2}$ in seawater:

$\left[\mathrm{CO}_{2}^{*}\right]=k_{0} \cdot f \mathrm{CO}_{2}$.

The solubility constant, $k_{0}$, relates the concentration of $\mathrm{CO}_{2}^{*}$ in seawater to the $\mathrm{CO}_{2}$ fugacity, $\mathrm{fCO}_{2}$. In contrast to the $\mathrm{CO}_{2}$ partial pressure, $\mathrm{pCO}_{2}$, the fugacity accounts for the nonideal behaviour of $\mathrm{CO}_{2}$ at atmospheric conditions. It differs only slightly from the $\mathrm{pCO}_{2}$ and in many cases can be replaced by the $\mathrm{pCO}_{2}$. The solubility and thus $k_{0}$ decrease with increasing temperature and salinity and vice versa. Studies by Weiss (1974) that describe $k_{0}$ as a function of temperature and salinity have received widespread acceptance and are almost exclusively used in chemical oceanography. The situation is somewhat more complicated for the determination of the dissociation constants for carbonic acid because it is a diprotic acid. Again using $\mathrm{CO}_{2} *$ as a variable, the two dissociation equilibria are given by

$$
\begin{aligned}
& K_{1}=\left[\mathrm{H}^{+}\right]\left[\mathrm{HCO}_{3}^{-}\right] /\left[\mathrm{CO}_{2}^{*}\right], \\
& K_{2}=\left[\mathrm{H}^{+}\right]\left[\mathrm{CO}_{3}^{2-}\right] /\left[\mathrm{HCO}_{3}^{-}\right] .
\end{aligned}
$$

In these formulas the terms for the hydrogen ions are given in concentration units which include $\mathrm{HSO}_{4}^{-}$ion concentration (Dickson, 1984). 


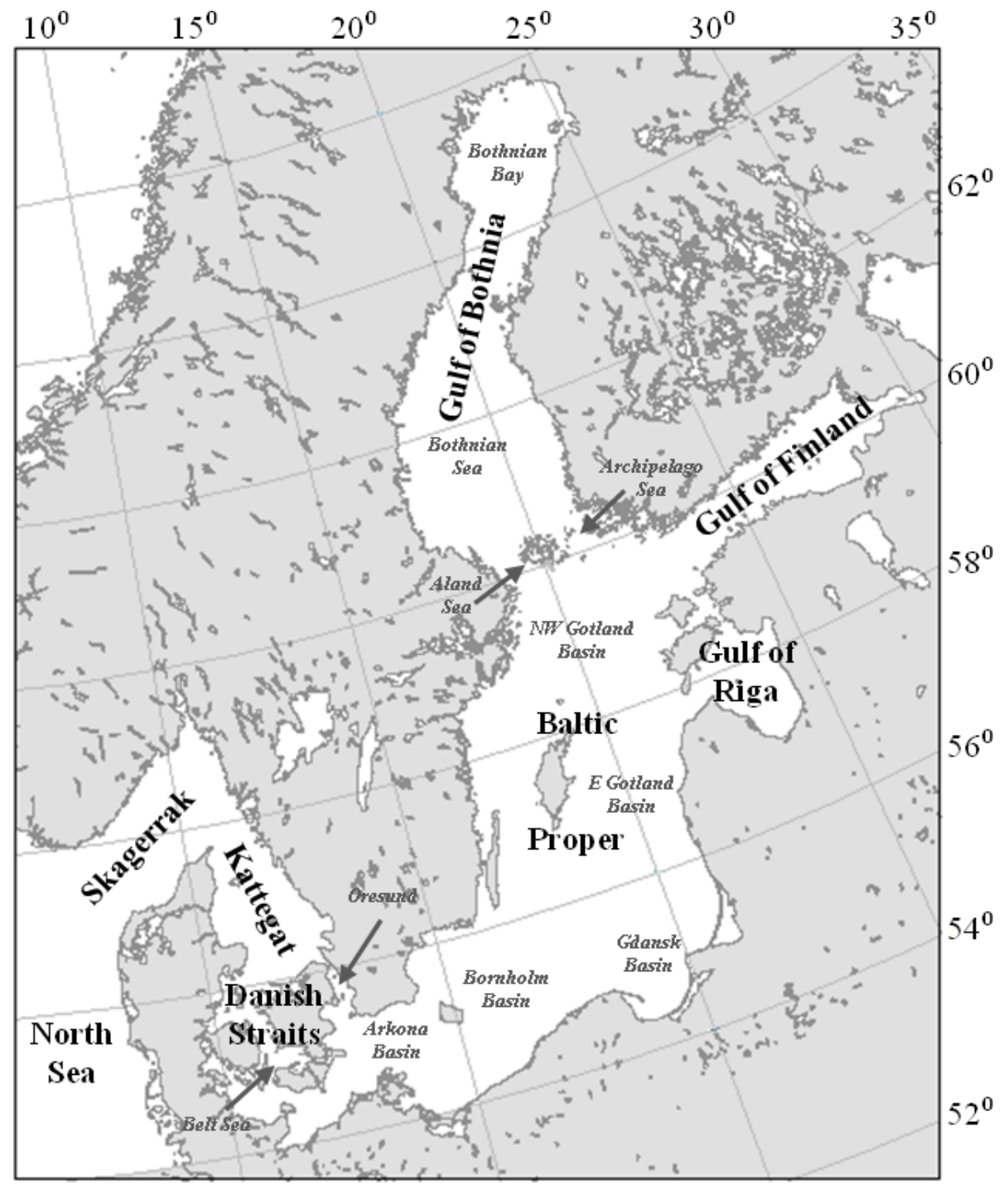

Figure 1. Map of the Baltic Sea showing its division into natural basins and sub-basins (modified after Kuliński and Pempkowiak, 2011).

Systematic studies concerning the dissociation constants of carbonic acid in seawater were already performed during the 20 s and 30 s of the last century. One of the leading scientists in this field was Kurt Buch from the former Finnish Institute for Marine Research, whose research was mainly related to the Baltic Sea and whose laboratory studies on the $\mathrm{CO}_{2}$ system focused on brackish water with salinities down to 0 . The results of his lab work and of field studies performed during 1927 to 1936 are summarized in Buch (1945). The presented dissociation constants must be considered "hybrid" constants because the hydrogen ions are represented by the hydrogen ion activity, whereas the $\mathrm{CO}_{2}$ constituents refer to concentrations.

With the increasing awareness of the importance of the oceans for the uptake of anthropogenic $\mathrm{CO}_{2}$ and thus for climate change scenarios, large-scale measurement programmes concerning the state of the marine $\mathrm{CO}_{2}$ system on an oceanic scale were performed. These efforts were accompanied by numerous laboratory studies aimed at the determination of improved dissociation constants. All these constants referred to the total hydrogen concentration scale that includes the contribution by $\mathrm{HSO}_{4}^{-}$(Dickson, 1984). However, the validity of most of the constants was confined to salinities that are encountered in ocean water. Exceptions are the constants suggested by Roy et al. (1993), which were determined for salinities down to values of 5 and could be used accordingly for brackish water. However, with regard to research in the Baltic Sea where large areas, e.g. in the Gulf of Bothnia, have surface water salinities less than 5 , the situation was unsatisfactory. This was the case until 2006 when Millero et al. (2006) published dissociation constants that covered the salinity range from 0 to 50 and that were consistent with the constants for freshwater. An update of these constants was performed in 2010 (Millero, 2010), and since 
then this set of dissociation constants is state of the art for $\mathrm{CO}_{2}$ research in brackish waters. The salinity and the temperature dependency of $K_{1}$ and $K_{2}$ are presented in Fig. 2a and $b$, respectively.

A direct comparison between the dissociation constants that were used in the past for brackish water is difficult because the constants by Buch (1945) are based on a pH scale that is based on the hydrogen ion activity. Since it is difficult to convert the activities to total hydrogen ion concentrations, we use the ratio $K_{1} / K_{2}$ for a comparison. This ratio is obtained by dividing the equilibrium equations for the first dissociation step (Eq. 4) through that of the second dissociation step (Eq. 5):

$\frac{K_{1}}{K_{2}}=\frac{\left[\mathrm{HCO}_{3}^{-}\right]^{2}}{\left[\mathrm{CO}_{2}^{*}\right] \cdot\left[\mathrm{CO}_{3}^{2-}\right]}$.

Equation (6) shows that $K_{1} / K_{2}$ is not connected to the hydrogen ion concentration and is thus not affected by the choice of the $\mathrm{pH}$ scale. Hence it is suited as an indicator of the quality of the early dissociation constants determined by Buch (1945). We used the logarithmic notation, $\log \left(K_{1} / K_{2}\right)$, which is equivalent to $\mathrm{p} K_{1}-\mathrm{p} K_{2}$, for a comparison of the dissociation constants suggested by Buch (1945), Millero (2010) and Roy et al. (1993). The differences $\Delta \log \left(K_{1} / K_{2}\right)$, referring to Millero (2010) and Buch (1945) and Millero (2010) and Roy et al. (1993) indicated as M-B and M-R, respectively, are shown as a function of salinity in Fig. 2c.

At salinities $>7$, M-R is less than 0.03 , but the differences increase rapidly at lower salinities and amount to 0.06 and 0.10 already at $S=5.4$ and $S=3.6$, respectively. Such differences in $\log \left(K_{1} / K_{2}\right)$ are equivalent to a temperature change of $1{ }^{\circ} \mathrm{C}$. The deviations of the Buch (1945) data from those of Millero (2010) (M-B in Fig. 2c) ranged below 0.10 at salinities below 20 . This is a surprisingly small difference in view of the limited technical capabilities that were available to Buch and his co-workers in the 20s and 30 s of the last century.

When alkalinity is also used for the calculation of any variables of the $\mathrm{CO}_{2}$ system, the contributions of non- $\mathrm{CO}_{2}$ acidbase components to $A_{\mathrm{T}}$ (Eq. 2), which are generally low, must be taken into account. This requires knowledge about the concentration of the individual acid-base pairs and about the corresponding dissociation constants. In the deep basins of the central Baltic Sea, ammonia and sulfide anions are released during organic-matter mineralization at anoxic conditions (see Sect. 3.4.2). Both these constituents are strong proton acceptors forming mainly $\mathrm{HS}^{-}$and $\mathrm{NH}_{4}^{+}$. Since their concentrations may be on the order of several tens and up to a few hundred $\mu \mathrm{mol} \mathrm{L}^{-1}$ (Nausch et al., 2008), respectively, they have a strong effect on alkalinity and $\mathrm{pH}$. Therefore, any calculations concerning the $\mathrm{CO}_{2}$ system at anoxic conditions must account for the dissociation equilibria of $\mathrm{H}_{2} \mathrm{~S}$ HS $^{-}$(Millero et al., 1988) and $\mathrm{NH}_{4}^{+}-\mathrm{NH}_{3}$ (Clegg and Whit-
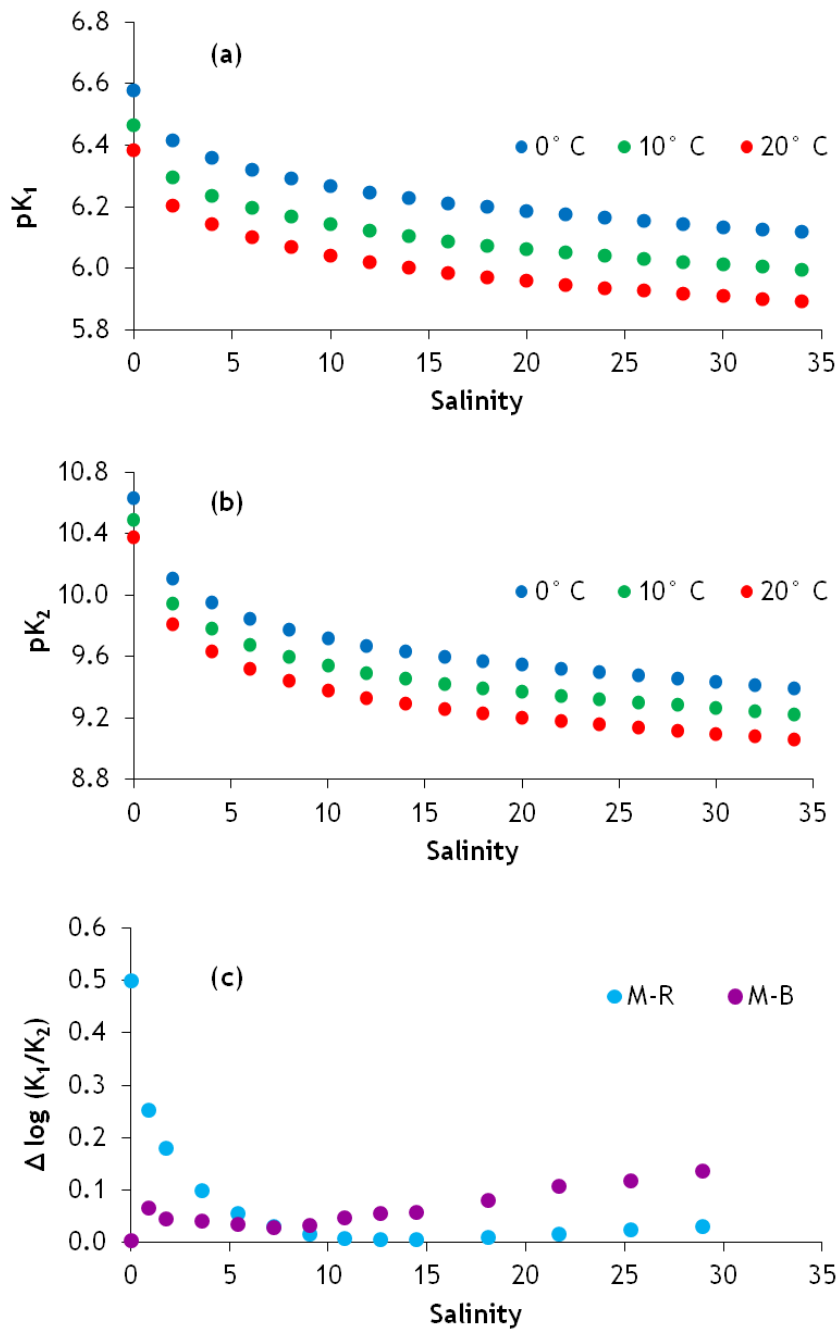

Figure 2. Dissociation constants (a) $\mathrm{p} K_{1}$ and (b) $\mathrm{p} K_{2}$ as a function of salinity calculated according to Millero (2010) for three different temperatures: 0,10 and $20^{\circ} \mathrm{C}$; (c) differences in $\log \left(K_{1} / K_{2}\right)$ between the dissociation constants obtained from Millero (2010) and Roy et al. (1993) (M-R, blue dots) and between Millero (2010) and Buch (1945) (M-B, purple dots) at different salinities.

field, 1995; Johansson and Wedborg, 1980). The concentrations of $\mathrm{S}^{2-}$ at the $\mathrm{pH}$ of anoxic water are extremely small and can be neglected.

\subsection{The central role of alkalinity}

\subsubsection{Regional $A_{\mathrm{T}}$ vs. $S$ distribution - consequences for $\mathrm{pH}$ distribution pattern}

There are several different $A_{\mathrm{T}}$ vs. $S$ regimes in the Baltic Sea. They reflect different $A_{\mathrm{T}}$ concentrations in the respective rivers, which can be deduced from extrapolation of regional $A_{\mathrm{T}}$ vs. $S$ relationships to zero salinity. Low alkalinities are observed in rivers entering the Gulf of Bothnia, whereas rivers from south-eastern part of the Baltic catchment, as 


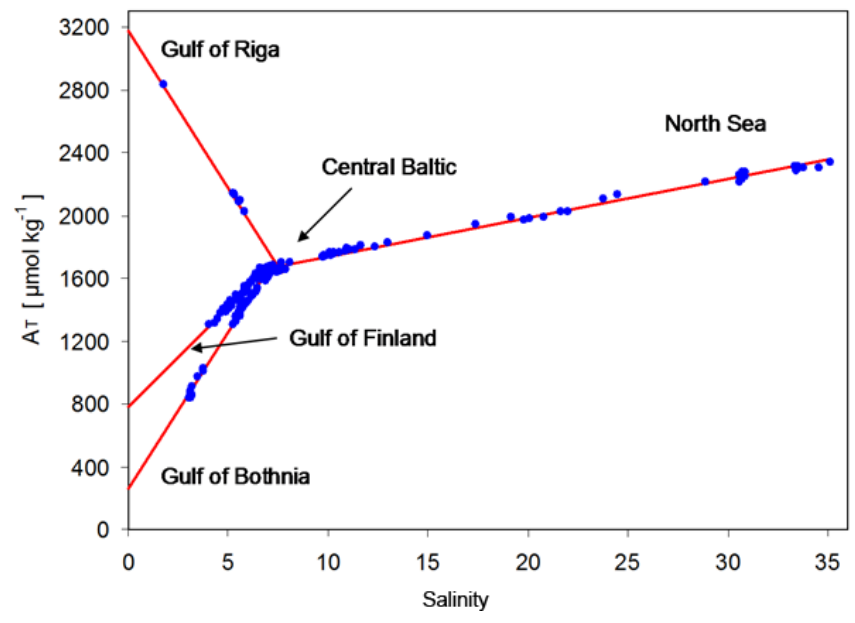

Figure 3. Different $A_{\mathrm{T}}$ vs. $S$ regimes observed in the Baltic Sea (modified after Beldowski et al., 2010).

shown by the $A_{\mathrm{T}}$ vs. $S$ plot for the Gulf of Riga (Fig. 3), are rich in alkalinity. These differences are a consequence of the geological conditions and weathering processes in the respective catchment areas. As a result lower alkalinities and lower mean $\mathrm{pH}$ are observed in the Gulf of Bothnia and Finland, whereas higher mean alkalinities and thus somewhat higher $\mathrm{pH}$ are found in the Gulf of Riga and also in Gdánsk Bay (Kulinski et al., 2014; Beldowski et al., 2010; Hjalmarsson et al., 2008).

The central Baltic Sea acts as a mixing chamber for the different water masses, including water originating from the North Sea. This results in alkalinity in the surface water of the Baltic Proper (salinity around 7) of about 1600$1700 \mu \mathrm{mol} \mathrm{kg} \mathrm{k}^{-1}$.

An important, but still not well investigated, aspect of the $A_{\mathrm{T}}$ supply to the Baltic Sea is the $A_{\mathrm{T}}$ seasonality in river water. As $A_{\mathrm{T}}$ is one of the variables used in biogeochemical models to study the $\mathrm{CO}_{2}$ system, well-described spatial and temporal variability in $A_{\mathrm{T}}$ loads could improve the characterization of the $A_{\mathrm{T}}$ distribution in the Baltic Sea and thus increase the accuracy of the modelled $\mathrm{pH}$ and $\mathrm{pCO}_{2}$. This could be achieved by the evaluation of the $A_{\mathrm{T}}$ monitoring data which are regularly collected by some Baltic Sea states within the framework of the HELCOM monitoring program. In some countries, such as Sweden, the monitoring data are publicly accessible; in others some limitations still exist.

$A_{\mathrm{T}}$ can also enter the Baltic Sea by submarine groundwater discharge (SGD). The chemical composition of groundwater, as in river water, depends to some extent on the geological structure of the catchment through which the water flows. Thus, SGD entering the Baltic Sea along the continental part of the coast can be rich in $A_{\mathrm{T}}$. Szymczycha et al. (2014) noticed significant $C_{\mathrm{T}}$ concentrations ( $5400 \mu \mathrm{mol} \mathrm{kg}{ }^{-1}$ on average) in SGD seeping to the southern Baltic along the Polish coast. Although there might be

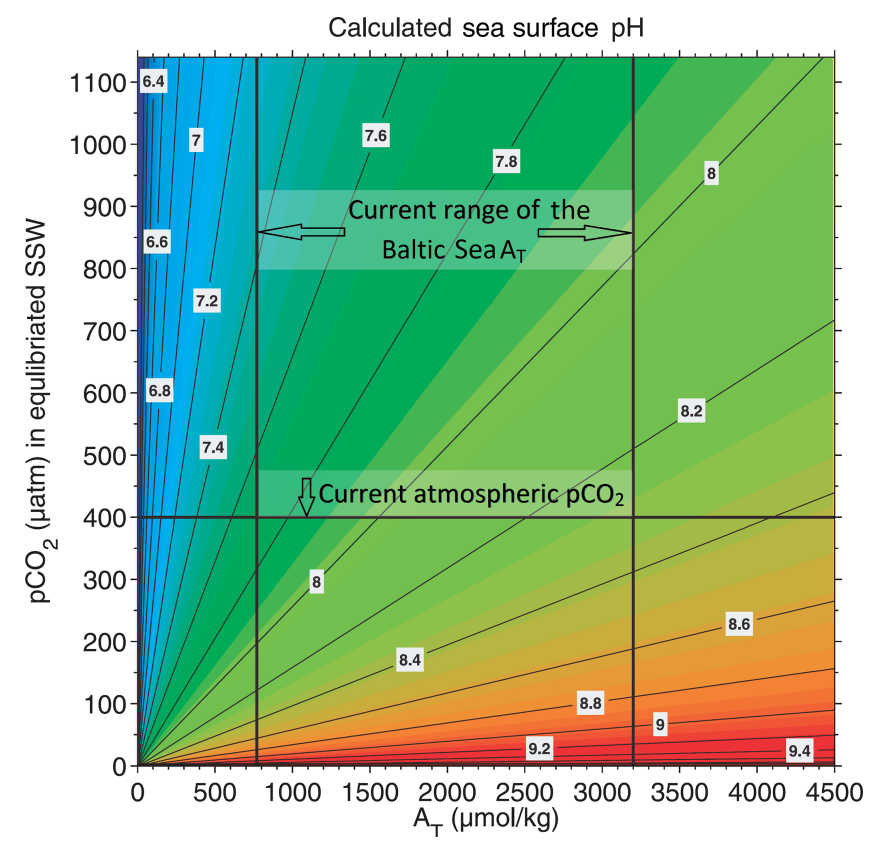

Figure 4. Distribution of $\mathrm{pH}_{\mathrm{tot}}$ as a function of $A_{\mathrm{T}}$ and $\mathrm{pCO}_{2}$ at a salinity of 7.5 and temperature of $0{ }^{\circ} \mathrm{C}$ (modified after Omstedt et al., 2010). The $A_{\mathrm{T}}$ range represents findings by Beldowski et al. (2010). SSW is an abbreviation for surface seawater.

some contribution from $\mathrm{CO}_{2}$ to this high $C_{\mathrm{T}}$, it is very likely that SGD can, at least locally, play an important role for the $A_{\mathrm{T}}$ budget. However, direct measurements of $A_{\mathrm{T}}$ concentrations and loads in SGD have not been reported in the Baltic Sea so far.

At equilibrium with the atmospheric $\mathrm{CO}_{2}, A_{\mathrm{T}}$ controls $C_{\mathrm{T}}$ and thus $\mathrm{pH}$. Hence, $\mathrm{pH}$ may be depicted as a function of $A_{\mathrm{T}}$ and $\mathrm{pCO}_{2}$. A sensitivity study performed by Omstedt et al. (2010) indicates that the $\mathrm{pH}$ of the Baltic Sea surface water that is at equilibrium with the atmosphere $\left(\mathrm{pCO}_{2}\right.$ of ca. $400 \mu$ atm at $0^{\circ} \mathrm{C}$ ) can vary between 7.7 and 8.3 depending on the $A_{\mathrm{T}}$ (Fig. 4). This range is significantly higher than that observed in the open ocean, where $A_{\mathrm{T}}$ oscillates only in a narrow range: $2170-2460 \mu \mathrm{mol} \mathrm{kg}^{-1}$ (Riebesell et al., 2010). The reason for that is the high spatial variability in $A_{\mathrm{T}}$ in the surface Baltic Sea waters, from low $A_{\mathrm{T}}$ (below $1000 \mu \mathrm{mol} \mathrm{kg}{ }^{-1}$ ) observed in the Bothnian Bay to the $A_{\mathrm{T}^{-}}$ rich (more than $3000 \mu \mathrm{mol} \mathrm{kg}^{-1}$ ) estuaries of the large continental rivers. The diagram presented in Fig. 4 also shows that higher $A_{\mathrm{T}}$ reduces shifts in seawater $\mathrm{pH}$ caused by changes in $\mathrm{pCO}_{2}$.

\subsubsection{Long-term $A_{\mathrm{T}}$ changes - consequences for ocean acidification}

Long-term high-resolution $\mathrm{pH}$ measurements at the BATS station (Bermuda Atlantic Time Series) in the subtropical North Atlantic have shown that ocean acidification occurs at a rate that is thermodynamically consistent with the increase 
in the atmospheric $\mathrm{CO}_{2}$ (Bates et al., 2014). There is therefore reason to expect that the progression of ocean acidification can be assessed on the basis of $\mathrm{CO}_{2}$ emission scenarios and the modelling of the effect on the atmospheric $\mathrm{CO}_{2}$. It also implies that changes in alkalinity will not occur in the future. On timescales of decades this may be a reasonable assumption for the oceans which react very slowly to internal or external changes. However, the situation is different for the Baltic Sea, which is under the immediate influence of natural and anthropogenic processes on land. The first hints of increasing alkalinity in the surface water of the central Baltic Sea were reported by Schneider et al. (2015), who argued that this may have considerably mitigated the acidification due to increasing atmospheric $\mathrm{CO}_{2}$. Müller et al. (2016) took up this idea and performed a thorough and comprehensive statistical analysis of all alkalinity data that were available since the start of $\mathrm{CO}_{2}$ research in the Baltic Sea at the beginning of the last century. The authors focused on high-quality data measured after 1995 and detected a distinct $A_{\mathrm{T}}$ trend that showed a clear regional gradient. The highest trend was found in the Gulf of Bothnia $\left(7.0 \mu \mathrm{mol} \mathrm{kg}^{-1} \mathrm{yr}^{-1}\right)$, followed by $3.4 \mu \mathrm{mol} \mathrm{kg}^{-1} \mathrm{yr}^{-1}$ in the central Baltic, whereas no trend could be detected in the Kattegat. Müller et al. (2016) estimated that the changes in $A_{\mathrm{T}}$ have reduced the acidification effect in the central Baltic Sea by about $50 \%$ and that the Gulf of Bothnia was not subjected at all to acidification during the last 20 years. Several reasons for the increasing $A_{\mathrm{T}}$ are discussed by Müller et al. (2016), but a major player could not be identified and, hence, it remains unclear whether the trend will continue in the future.

\subsubsection{Effect of organic alkalinity}

The Baltic Sea water contains 3-5 times more organic matter than open-ocean waters. In the surface water of the open Baltic Sea, concentrations of dissolved organic carbon (DOC) range from about 260 to about $480 \mu \mathrm{mol} \mathrm{CL}^{-1}$, while those in the surface water (top $100 \mathrm{~m}$ ) of the Atlantic Ocean are much lower and range between 50 and $80 \mu \mathrm{mol} \mathrm{C} \mathrm{L}^{-1}$ (Hoikkala et al., 2015; Carlson et al., 2010). This is a result of both high inputs of terrestrial organic matter and eutrophication driven by nutrient supply from land (Hoikkala et al., 2015; Kuliński and Pempkowiak, 2011; Kuliński et al., 2011). Organic substances contain functional groups, some of which (carboxylic, phenolic, amines) have an acidic character and can dissociate in seawater, releasing protons $\left(\mathrm{H}^{+}\right)$. This contributes to $\mathrm{pH}$ decrease. However, as most of these groups are believed to act as weak acids ( $\left.\mathrm{p} K_{\mathrm{a}}>4.5\right)$, their dissociation releases the equivalent of organic acids, which are strong bases. This, according to Eq. (2), causes no change in $A_{\mathrm{T}}$ concentration since an equivalent amount of protons have been released. It affects the internal structure of $A_{\mathrm{T}}$ by changing the contributions of different $A_{\mathrm{T}}$ components according to their individual dissociation constants (Cai et al., 1998; Hunt et al., 2011; Kuliński et al.,
2014). The lower the $\mathrm{p} K_{\mathrm{a}}$ of an organic acid added to the system, the greater are the shifts in the internal $A_{\mathrm{T}}$ distribution. As a consequence bases forming the acid-base system are partially protonated and their concentration decreases while the concentration of the corresponding undissociated acid is increasing. In the case of the carbonate alkalinity, this means a reduction in $\mathrm{CO}_{3}^{2-}$ and an increase in $\mathrm{H}_{2} \mathrm{CO}_{3}$ and thus the $\mathrm{pCO}_{2}$.

Kuliński et al. (2014) estimated the organic alkalinity $\left(A_{\text {org }}\right)$ in the Baltic Sea as an excess alkalinity calculated from the difference between measured $A_{\mathrm{T}}$ and that calculated from $C_{\mathrm{T}}$ and $\mathrm{pH}$ or $\mathrm{pCO}_{2}$. They found $A_{\text {org }}$ of $25-35 \mu \mathrm{mol} \mathrm{kg}{ }^{-1}$ in the surface Baltic Sea water (from the Arkona Basin to the Bothnian Bay) without any clear spatial distribution pattern. This $A_{\text {org }}$ contribution amounted from 1.5 to $3.5 \%$ of the measured $A_{\mathrm{T}}$ values. Even higher values of more than $50 \mu \mathrm{mol} \mathrm{kg}{ }^{-1}$ were found by Hammer et al. (2017) in the Baltic Sea surface mixed layer during the spring phytoplankton bloom. They reported also that $A_{\text {org }}$ decreases with depth and approaches 0 below the permanent halocline due to $\mathrm{pH}$ decrease.

In sensitivity studies Kuliński et al. (2014) showed for the Baltic Sea that calculations concerning the $\mathrm{CO}_{2}$ system that use measured $A_{\mathrm{T}}$ may lead to significant errors if $A_{\text {org }}$ is ignored. Highest deviations between calculated and observed values were found when $A_{\mathrm{T}}$ was used together with $C_{\mathrm{T}}$ for computations of $\mathrm{pCO}_{2}$ and $\mathrm{pH}$. The $\mathrm{pCO}_{2}$ values obtained in that way were $27-56 \%$ lower than the measured ones, while $\mathrm{pH}$ was overestimated by more than 0.4 units. These results are especially important as this combination $\left(A_{\mathrm{T}}\right.$ and $\left.C_{\mathrm{T}}\right)$ is used in biogeochemical models (Edman and Omstedt, 2013; Kuznetsov and Neumann, 2013; Omstedt et al., 2009, 2012) because they are conservative variables. This means that they are independent of pressure and temperature and follow the law of conservation of mass during mixing, which are prerequisites for variables transported in models. The first attempts to include an $A_{\text {org }}$ parameterization in biogeochemical models were made by Gustafsson et al. (2015) and Omstedt et al. (2015). However, the sensitivity of the models with regard to the inclusion/negligence of $A_{\text {org }}$ has not yet been reported.

The source of the calculation errors related to ignoring $A_{\text {org }}$ is due to the fact that measurements include all inorganic and organic contributors, while subsequent calculations using the standard chemical $A_{\mathrm{T}}$ model and respective software interpret the measured $A_{\mathrm{T}}$ only as inorganic alkalinity. Including organic substances into the $A_{\mathrm{T}}$ model is, however, challenging as there are a number of organic substances having acidic functional groups, and, according to the $A_{\mathrm{T}}$ definition, for each of them the information on concentration and dissociation constants must be available. Accounting for $A_{\text {org }}$ in the chemical $A_{\mathrm{T}}$ model is less important for oceanic research because the low concentrations of dissolved organic matter (DOM) in the oceans cause only minor effects. As a first approximation of the acid-base properties of DOM for the Baltic Sea water, Kuliński et al. (2014) proposed to 
use one single bulk dissociation constant, $\mathrm{p} K_{\mathrm{DOM}}$, and relate $A_{\text {org }}$ to the concentration of DOC, a commonly measured parameter. According to their studies, slightly corrected by Ulfsbo et al. (2015), $\mathrm{p} K_{\mathrm{DOM}}$ in the Baltic Sea amounts to 7.34. They also estimated experimentally that $12 \%$ of DOC acts as a carrier for acidic functional groups in the Baltic Sea DOM. The model studies by Ulfsbo et al. (2015) showed that this experimentally derived share fits the share estimated from the hypothetical structure of the fulvic acids. They also suggested that the method proposed by Kuliński et al. (2014) is the best available approach for representing organic alkalinity in biogeochemical models at the current state of knowledge. They also showed that organic matter (as represented by the fulvic acids) also contains some functional groups having $\mathrm{p} K_{\mathrm{a}}$ already below 4.5. According to the definition (Dickson, 1981), they should be considered strong acids. In experimental studies Hammer et al. (2017) also found that humic and/or fulvic substances are more acidic than the bulk DOM naturally occurring in the Baltic Sea. This may also be a source of uncertainty in the $A_{\mathrm{T}}$ measurements as the determination of the titration end-point requires the titration of the samples through this $\mathrm{pH}$ region.

\subsubsection{Role of borate alkalinity}

The carbonate system plays a central role in the marine acidbase system. Thus, studies on seawater $\mathrm{pH}$ and buffering capacity usually focus on the carbon species. Less attention is paid to boron, though borates are, after bicarbonates and carbonates, the third most abundant constituent of seawater $A_{\mathrm{T}}$ (Eq. 2). Boron exists in seawater in the form of weak boric acid, $\mathrm{B}(\mathrm{OH})_{3}$, and the anion, $\mathrm{B}(\mathrm{OH})_{4}^{-}$. The high $\mathrm{p} K_{\mathrm{a}}(8.60$ at salinity 35 and temperature $25^{\circ} \mathrm{C}$ ) means that at a seawater $\mathrm{pH}$ of about 8 , the undissociated boric acid predominates. The boron concentration, $B_{\mathrm{T}}$, in seawater is approximated as a function of salinity or, for the historical data, as a function of chlorinity $(S=1.80655 \cdot \mathrm{Cl})$. First measurements of boron concentrations in the Baltic Sea were reported by Buch (1945), who found that $B_{\mathrm{T}}\left[\mathrm{mg} \mathrm{kg}^{-1}\right]=0.133 \cdot S$. This finding was confirmed recently by Lee et al. (2010) for oceanic waters. Another relationship linking $B_{\mathrm{T}}$ and $S$ and often used in acid-base system studies is that by Uppström (1974), who reported that $B_{\mathrm{T}}\left[\mathrm{mg} \mathrm{kg}^{-1}\right]=0.128 \cdot S$. All these formulas suggest a fixed $B_{\mathrm{T}} / S$ ratio, which is only the case if the river water that enters the Baltic Sea contains no boron. However, the studies by Kremling $(1970,1972)$ indicated that this is not the case and that a $B_{\mathrm{T}}$ concentration anomaly exists in the Baltic Sea, where the experimentally determined $B_{\mathrm{T}}$ vs. $S$ relationship yielded a river water $B_{\mathrm{T}}$ (anomaly term) of $0.15-0.20 \mathrm{mg} \mathrm{kg}^{-1}$ at $S=0$. This anomaly is not included in the chemical $A_{\mathrm{T}}$ model commonly used for numerical simulations of the $\mathrm{CO}_{2}$ system and, similar to the effects of ignoring $A_{\text {org }}$, may lead to wrong conclusions. This can be especially critical at low salinities, where the effect of the anomaly is the largest.

\subsection{Modulation of the acid-base system by organic-matter production/mineralization (concurrent $A_{\mathrm{T}}$ and $C_{\mathrm{T}}$ changes)}

\subsubsection{Biomass production}

In the case of $\mathrm{pH}$ changes referring to equilibrium with the atmosphere, it may be meaningful to consider the $\mathrm{pH}$ at a given alkalinity as a function of $\mathrm{pCO}_{2}$ because the atmospheric $\mathrm{CO}_{2}$ is then the only driver for any $\mathrm{pH}$ changes. However, when assessing $\mathrm{pH}$ changes as the consequence of internal biogeochemical transformations, it is more appropriate to consider $A_{\mathrm{T}}$ and $C_{\mathrm{T}}$ as the controls for $\mathrm{pH}$ and $\mathrm{pCO}_{2}$. Biomass production primarily alters $C_{\mathrm{T}}$ because phytoplankton (but also other plants) consume $\mathrm{CO}_{2}$ in the course of photosynthesis (Fig. 5). As a consequence it increases the $\mathrm{pH}$ and lowers the $\mathrm{pCO}_{2}$ in the upper water layers and causes a $\mathrm{pCO}_{2}$ disequilibrium between seawater and the atmosphere. This leads to $\mathrm{CO}_{2}$ uptake by the seawater and thus counteracts the effect of biomass production and dampens the $\mathrm{pH}$ increase. However, the $\mathrm{CO}_{2}$ exchange through the air-sea interface is much slower than the effects of biological processes. Therefore, the Baltic Sea water is in almost permanent $\mathrm{pCO}_{2}$ disequilibrium with the atmosphere throughout the year. In spring and summer, seawater is undersaturated with respect to atmospheric $\mathrm{CO}_{2}$ with two characteristic $\mathrm{pCO}_{2}$ minima and two $\mathrm{pH}$ maxima (Fig. 5), which reflect the spring bloom and the midsummer nitrogen fixation period. In autumn and winter the Baltic Sea surface water $\mathrm{pCO}_{2}$ increases over the atmospheric values as a consequence of less active production in the upper water column and transport of deeper $\mathrm{CO}_{2-}$ enriched water to the surface by mixing (Fig. 5; Schneider, 2011).

Another way in which biomass production influences seawater $\mathrm{pH}$ and $\mathrm{pCO}_{2}$ is related to nitrate consumption. As phytoplankton assimilate nitrate for growth, an equivalent of $\mathrm{H}^{+}$ is also transported to the cells to keep the charge balance neutral. According to Eq. (2) this increases the seawater $A_{\mathrm{T}}$ and thus raises the $\mathrm{pH}$ during biomass production (Brewer and Goldman, 1976). This assimilation also decreases the $\mathrm{pCO}_{2}$ and therefore reinforces the drop in $\mathrm{pCO}_{2}$ by biomass production. Some small $A_{\mathrm{T}}$ changes can be also induced by phosphate consumption. However, due to low phosphate concentration the effect is negligible (Wolf-Gladrow et al., 2007).

Biological production may also consume $\mathrm{CO}_{3}^{2-}$ ions in the calcification processes. This causes an $A_{\mathrm{T}}$ reduction and in consequence a $\mathrm{pCO}_{2}$ increase and also a $\mathrm{pH}$ decrease. However, this mechanism has been recognized as less important in the Baltic Sea. According to studies by Tyrrell et al. (2008), the Baltic Sea surface water is undersaturated in winter with respect to both aragonite and calcite, which are biogenic modifications of $\mathrm{CaCO}_{3}$. This possibly prevents the growth of calcifying plankton and is the reason for the absence of coccolithophores in the Baltic Sea. 


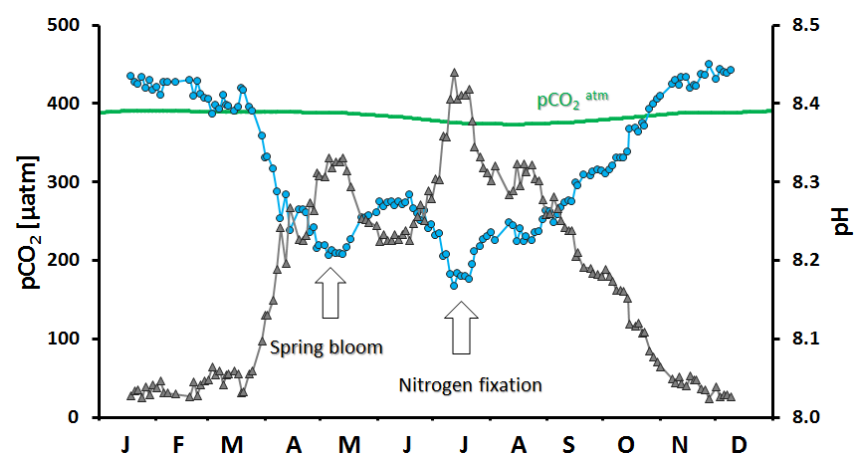

Figure 5. Typical seasonality of $\mathrm{pCO}_{2}$ in surface water (blue line) and the atmosphere (green line) in the Eastern Gotland Sea modified after Schneider (2011) and presented together with pH calculated from the shown $\mathrm{pCO}_{2}$ data and the mean $A_{\mathrm{T}}$ value.

\subsubsection{Remineralization}

In contrast to biomass production, $\mathrm{CO}_{2}$ is released during the remineralization processes and causes an increase in $C_{\mathrm{T}}$. Consequently, this leads to a $\mathrm{pH}$ decrease and $\mathrm{pCO}_{2}$ increase. Some fraction of organic matter produced in situ undergoes remineralization in the upper water layers. Particulate organic matter (POM) may be mineralized directly or via the prior release of DOM. In the Baltic Sea terrigenous organic matter entering the sea from rivers constitutes an important part of the organic matter. Kuliński and Pempkowiak (2011) reported that the Baltic Sea receives $340 \mathrm{Gmol}$ of organic carbon from land annually. The model studies by Gustafsson et al. (2014a) suggested that as much as $39.5 \%$ of terrigenous organic carbon that enters the Baltic Sea undergoes mineralization without distinguishing between mineralization pathways. This makes it difficult to estimate all the consequences of that terrestrial organic carbon loss for the Baltic Sea acid-base system. The incubation experiments performed by Kuliński et al. (2016) indicated that ca. $20 \%$ of terrestrial dissolved organic carbon and $34 \%$ of DOC present in the Baltic Sea is bioavailable. It is important to mention here that the latter result likely refers to the mixture of terrestrial and marine DOC.

Whereas the $A_{\mathrm{T}}$ in surface water is mainly controlled by the mixing of different water masses, the deep-water $A_{\mathrm{T}}$ distribution additionally depends on the organic-matter transformations by various redox processes (Brenner et al., 2016; Krumins et al., 2013; Thomas et al., 2009; Schulz and Zabel, 2006). A certain fraction of the organic matter produced in the euphotic zone is exported to deeper water layers and to surface sediments, where it undergoes mineralization, produces $\mathrm{CO}_{2}$ and changes the alkalinity. The change in $A_{\mathrm{T}}$ depends on the oxidant that is required for the mineralization and may cover a wide range. Therefore, it is not possible to predict the change in $\mathrm{pH}$ or $\mathrm{pCO}_{2}$ during the mineralization process without knowledge of the oxidant. In the presence of oxygen, mineralization takes place according to Eq. (7), which reverses the bulk photosynthesis reaction. However, in sediments and in deep-water layers of some basins of the central Baltic, where longer periods (years) of stagnation occur, oxygen may be entirely depleted. Organic matter can then be mineralized in a certain thermodynamically controlled sequence by other oxidants (Schulz and Zabel, 2006). First, manganese dioxide takes over the role of oxygen (Eq. 8), followed by denitrification where nitrate acts as an oxidant (Eq. 9). After nitrate is consumed, the mineralization process may be continued by iron (III) oxide (Eq. 10) before sulfate oxidizes the organic matter and generates hydrogen sulfide (Eq. 11). In the Baltic Sea these processes may take place in the water column where a pelagic redoxcline (an interface between oxic and anoxic conditions) can develop during longer periods of stagnation. Only the final mineralization, that is an internal oxidation and generates methane (methanogenesis, Eq. 12) after the sulfate concentration has approached 0 , is confined to deeper sediment layers only. Except for oxic mineralization, all other processes are connected with a simultaneous $A_{\mathrm{T}}$ increase caused either by the release of strong bases $\left(\mathrm{S}^{2-}\right.$ ) or by the consumption of $\mathrm{H}^{+}$(see Eq. 2) (Ulfsbo et al., 2011; Schneider et al., 2015; Lukawska-Matuszewska, 2016). The change in $A_{\mathrm{T}}\left(\Delta A_{\mathrm{T}}\right)$ for different mineralization pathways is given in moles $A_{\mathrm{T}}$ per 106 moles of released $\mathrm{CO}_{2}$ (Eqs. 7-12). It shows large differences and is highest when the insoluble oxides of iron (III) and manganese (IV) are reduced during the mineralization process. As a consequence of the higher $A_{\mathrm{T}}$ level, the $\mathrm{pCO}_{2}$ increase and $\mathrm{pH}$ decrease by increasing $C_{\mathrm{T}}$ during the mineralization is mitigated or may even be reversed. In the Eastern Gotland Sea these mechanisms stabilize the $\mathrm{pH}$ in the deep, anoxic water layers at a level of about 7 (Hammer et al., 2017).

$$
\begin{aligned}
& \left(\mathrm{CH}_{2} \mathrm{O}\right)_{106}\left(\mathrm{NH}_{3}\right)_{16}\left(\mathrm{H}_{3} \mathrm{PO}_{4}\right)+138 \mathrm{O}_{2} \\
& \rightarrow 106 \mathrm{CO}_{2}+16 \mathrm{H}^{+}+16 \mathrm{NO}_{3}^{-}+122 \mathrm{H}_{2} \mathrm{O}+\mathrm{H}_{3} \mathrm{PO}_{4}
\end{aligned}
$$

Oxic mineralization, $\Delta A_{\mathrm{T}}=-16$.

$$
\begin{aligned}
& \left(\mathrm{CH}_{2} \mathrm{O}\right)_{106}\left(\mathrm{NH}_{3}\right)_{16}\left(\mathrm{H}_{3} \mathrm{PO}_{4}\right)+236 \mathrm{MnO}_{2}+472 \mathrm{H}^{+} \\
& \rightarrow 236 \mathrm{Mn}^{2+}+106 \mathrm{CO}_{2}+8 \mathrm{~N}_{2}+366 \mathrm{H}_{2} \mathrm{O}+\mathrm{H}_{3} \mathrm{PO}_{4} .
\end{aligned}
$$

Manganese reduction, $\Delta A_{\mathrm{T}}=+472$.

$$
\begin{aligned}
& \left(\mathrm{CH}_{2} \mathrm{O}\right)_{106}\left(\mathrm{NH}_{3}\right)_{16}\left(\mathrm{H}_{3} \mathrm{PO}_{4}\right)+84.8 \mathrm{H}^{+}+84.8 \mathrm{NO}_{3}^{-} \\
& \rightarrow 106 \mathrm{CO}_{2}+42.4 \mathrm{~N}_{2}+16 \mathrm{NH}_{3}+148.4 \mathrm{H}_{2} \mathrm{O}+\mathrm{H}_{3} \mathrm{PO}_{4} .
\end{aligned}
$$

Denitrification, $\Delta A_{\mathrm{T}}=+100.8$.

$$
\begin{aligned}
& \left(\mathrm{CH}_{2} \mathrm{O}\right)_{106}\left(\mathrm{NH}_{3}\right)_{16}\left(\mathrm{H}_{3} \mathrm{PO}_{4}\right)+212 \mathrm{Fe}_{2} \mathrm{O}_{3}+848 \mathrm{H}^{+} \\
& \rightarrow 424 \mathrm{Fe}^{2+}+106 \mathrm{CO}_{2}+16 \mathrm{NH}_{3}+530 \mathrm{H}_{2} \mathrm{O}+\mathrm{H}_{3} \mathrm{PO}_{4} .
\end{aligned}
$$

Iron reduction, $\Delta A_{\mathrm{T}}=+864$. 


$$
\begin{aligned}
& \left(\mathrm{CH}_{2} \mathrm{O}\right)_{106}\left(\mathrm{NH}_{3}\right)_{16}\left(\mathrm{H}_{3} \mathrm{PO}_{4}\right)+53 \mathrm{SO}_{4}^{2-} \\
& \rightarrow 106 \mathrm{CO}_{2}+16 \mathrm{NH}_{3}+53 \mathrm{~S}^{2-}+106 \mathrm{H}_{2} \mathrm{O}+\mathrm{H}_{3} \mathrm{PO}_{4} .
\end{aligned}
$$

Sulfate reduction, $\Delta A_{\mathrm{T}}=+122$.

$$
\begin{aligned}
& \left(\mathrm{CH}_{2} \mathrm{O}\right)_{106}\left(\mathrm{NH}_{3}\right)_{16}\left(\mathrm{H}_{3} \mathrm{PO}_{4}\right) \\
& \rightarrow 53 \mathrm{CO}_{2}+53 \mathrm{CH}_{4}+16 \mathrm{NH}_{3}+\mathrm{H}_{3} \mathrm{PO}_{4} .
\end{aligned}
$$

Methanogenesis, $\Delta A_{\mathrm{T}}=+16$.

Generally, benthic processes linked to early diagenesis of organic matter can be an important source of $A_{\mathrm{T}}$ to the water column (Brenner et al., 2016). This corresponds to the findings by Gustafsson et al. (2014b), who, in a model study, found that external sinks and sources of $A_{\mathrm{T}}$ in the Baltic Sea are imbalanced and cannot reproduce the observed $A_{\mathrm{T}}$ inventory and that an internal $A_{\mathrm{T}}$ source must exist in the Baltic Sea. However, it must be taken into account that alkalinity released from sediments as sulfide or ammonia only influences the acid-base system locally. Upon contact with oxic water, most of the $A_{\mathrm{T}}$-generating processes except for denitrification - are reversed and do not constitute a permanent $A_{\mathrm{T}}$ source. Some minor increase in $A_{\mathrm{T}}$ can be also expected due to the burial of iron (II) minerals like pyrite or vivianite (Reed et al., 2016).

\section{Challenges for future research}

General knowledge of the marine acid-base system has been gained mainly from oceanic research. It has been integrated and documented in the form of a guide (Dickson et al., 2007) and included in different software packages (Orr et al., 2015), which allow for computations of two out of the four acidbase system parameters $\left(\mathrm{pCO}_{2}, \mathrm{pH}, A_{\mathrm{T}}, C_{\mathrm{T}}\right)$, when the other two are known (e.g. by measurements). Although this works nicely for the open-ocean waters, problems appear when that knowledge is used for studying the acid-base-system-related processes in coastal and shelf seas. This uncovers research gaps and limitations but also define challenges for marine biogeochemists working in these regions.

In this context the Baltic Sea can be considered a model experimental field, where strong horizontal and vertical salinity gradients, permanent stratification of the water column, eutrophication, high organic-matter concentrations, and high anthropogenic pressure make the acid-base system even more entangled. The challenges are related to analytical methods, interpretation of the data and parameterization of the acid-base-system-related processes for use in numerical models. Great effort has recently been made to adapt spectrophotometric $\mathrm{pH}$ measurements based on m-cresol purple to Baltic Sea conditions. This was done by Hammer et al. (2014) and was recently improved within the framework of the BONUS PINBAL project. Further progress can be expected if $\mathrm{pH}$ reference materials for brackish water are made available in the future. For the $\mathrm{pCO}_{2}$ measurements the stateof-the-art method that is based on measuring the $\mathrm{CO}_{2}$ content in air equilibrated with the seawater is commonly used (e.g. Schneider et al., 2014). Due to a relatively long response time, this method may, however, not be fast enough to resolve steep horizontal $\mathrm{pCO}_{2}$ gradients in the vicinities of river mouths. The development of accurate and precise sensors for $\mathrm{pCO}_{2}$, like optodes, could improve our understanding of the $\mathrm{CO}_{2}$ system in the transition area from the coast to the open sea. Additionally, it would facilitate $\mathrm{pCO}_{2}$ measurements in discrete samples, which are highly desired for investigations of the organic-matter mineralization processes in the water column but difficult to obtain with common underway measurement techniques. The determination of $A_{\mathrm{T}}$ by titration with an acid ( $\mathrm{HCl})$ allows a high accuracy $\left( \pm 2 \mu \mathrm{mol} \mathrm{kg}{ }^{-1}\right)$ for ocean water. This is difficult to achieve for Baltic Sea water because the detection of the endpoint of the $A_{\mathrm{T}}$ titration is more difficult due to the influence of organic acid-base constituents. The studies by Ulfsbo et al. (2015) showed that fulvic and humic acids, substances commonly found in the Baltic Sea, have relatively high concentrations of acid-base constituents, which have $\mathrm{p} K_{\mathrm{a}}$ values close to the $\mathrm{p} K_{\mathrm{a}}$ of carbonic acid and may thus impede the correct detection of the titration endpoint. $C_{\mathrm{T}}$ measurements are less critical since reference materials exist and the analytical procedure is relatively straightforward. However, the development of highaccuracy underway methods for $C_{\mathrm{T}}$ (but also $A_{\mathrm{T}}$ ) would improve the horizontal coverage of the data.

Interpretations of the acid-base system data require an appropriate parameterization of the related processes and chemical reactions. With regard to the Baltic Sea some peculiarities of the composition of the acid-base system must be taken into account, which are neglectable in ocean waters. An example is the influence of DOM on the acid-base system. In the oceans, it is ignored due to low DOM concentrations, but in the Baltic Sea $A_{\text {org }}$ becomes a noticeable component of $A_{\mathrm{T}}$ (Kuliński et al., 2014). The challenge remains to include the contribution by DOM in the chemical $A_{\mathrm{T}}$ model. The approach suggested by Kuliński et al. (2014) to use the so-called bulk dissociation constant, $K_{\mathrm{DOM}}$, is only a first approximation, as $K_{\mathrm{DOM}}$ has no real thermodynamic meaning. It also does not allow for distinguishing the influence of individual substances. Respective improvements would require substantial progress in analytical techniques, as the characterization of the structure and composition of DOM is still far from being satisfactory (Nebbioso and Piccolo, 2013). Problems also arise due to the ion anomalies observed in the Baltic Sea (Kremling, 1970, 1972) that are not taken into account in the $A_{\mathrm{T}}$ model. An example is boron, whose concentration is usually approximated by the assumption of a constant boron / salinity ratio. However, the function linking both these parameters does not account for river water as a source of boron. Furthermore, common software for $\mathrm{CO}_{2}$ system calculation also omits seawater constituents that are generated at anoxic conditions. These are mainly the acid- 
base reactions: $\mathrm{H}_{2} \mathrm{~S}-\mathrm{HS}^{-}-\mathrm{S}^{2-}$ and $\mathrm{NH}_{4}^{+}-\mathrm{NH}_{3}$, which require consideration in computational models. All these shortcomings may cause uncertainties in any calculations of the $\mathrm{CO}_{2}$ system including those in biogeochemical models when $A_{\mathrm{T}}$ is used as a controlling variable. It is also recommended to perform sensitivity studies in order to estimate the quantitative importance of inadequate chemical characterization of $A_{\mathrm{T}}$.

Furthermore, we promote the implementation of the acidbase system (or marine $\mathrm{CO}_{2}$ system) into biogeochemical models. This includes the simulation of surface water $\mathrm{CO}_{2}$ partial pressure, $\mathrm{pCO}_{2}$. The $\mathrm{pCO}_{2}$ is an ideal validation variable because on the one hand, it can easily be measured with high spatiotemporal resolution (e.g. on Voluntary Observing Ships, VOSs) and, on the other hand, it reflects the biogeochemical transformations such as biomass production. Hence, agreement between simulated and measured $\mathrm{pCO}_{2}$ data gives an indication of the quality of the biogeochemical process parameterization. Or, vice versa, unsatisfactory agreement gives reason to rethink the description of the respective processes in the model.

The latter aspect was the focus of several model studies which initially failed to reproduce the observed $\mathrm{pCO}_{2}$ drawdown during spring and summer (Fig. 5). This indicated that the traditional parameterization of the biomass production that is based on the Redfield (1963) $C / N / P$ ratios and on nutrient concentrations at the start of the productive period did not reflect the reality. Omstedt et al. (2009) solved the problem by including a fractional nutrient release into their model. This meant that nutrients that have been used for production are partly released from the POM and reused for new production. In another study Kuznetsov et al. (2011) introduced an additional cyanobacteria group and flexible $C / N / P$ ratios into their model in order to achieve approximate agreement between the simulated and measured $\mathrm{pCO}_{2}$. A further study by Gustafsson et al. (2014a) investigated the changes in the simulated $\mathrm{CO}_{2}$ air-sea flux after including organic alkalinity and changes in external inputs of carbon, alkalinity and nutrients. Modelling the $\mathrm{CO}_{2}$ system was also used to simulate the vertical distribution of total $\mathrm{CO}_{2}$ and alkalinity in stagnant waters of the deep basins (Edman and Omstedt, 2013) and to assess the importance of internal alkalinity generation (Gustafsson et al., 2014b). Finally, model calculations were used to estimate future changes in the Baltic Sea $\mathrm{CO}_{2}$ system and in particular in the development of the ocean acidification effect (Omstedt et al., 2012; Kuznetzov and Neumann, 2013). Both simulations indicated that the increasing atmospheric $\mathrm{CO}_{2}$ will mainly control long-term changes in $\mathrm{pH}$, of course, not taking into account the recently reported current increase in alkalinity (see Chap. 3.3.2; Müller et al., 2016).

\section{Summary and conclusions}

With our review we have proposed that the Baltic Sea acidbase system cannot be explained by dissolved $\mathrm{CO}_{2}$ and a minor contribution of boric acid. Whereas acid-base components other than $\mathrm{CO}_{2}$ and borate may be ignored in ocean waters, this is not the case in the Baltic Sea and, presumably, other marginal and semi-enclosed seas, which in a similar way are strongly impacted by high biomass production and natural and anthropogenic processes in connected catchment areas as well. The complexity of the Baltic Sea acidbase system is displayed in the formulation of the alkalinity (Eq. 2), which is the central variable for the characterization of the acid-base properties of seawater. The peculiarities of the Baltic Sea alkalinity system are either caused by specific internal processes related to the intense production/mineralization of organic matter or to the immediate effect of riverine input of acidic substances. This riverine input refers mostly to dissolved organic matter, which may strongly affect the composition of the alkalinity in the Baltic Sea surface water (Kuliński et al., 2014), but also to boric acid (borate), which in ocean water is linked to salinity by a constant ratio but may show distinct deviations from this ratio in some of the Baltic Sea estuaries because of boron input by river water.

Internal biogeochemical processes such as organic-matter production or mineralization also have the potential to affect the acid-base system in the Baltic Sea. Alkalinity changes by organic-matter production caused by the removal of $\mathrm{H}^{+}$during the uptake of nitrate are of minor importance. This may be different if the production is associated with calcification, which reduces the alkalinity, but the abundance of calcifying plankton in the Baltic Sea is restricted to the high-salinity Kattegat region. Although the effect of organic-matter production on alkalinity is minor, it is the major control for the seasonal modulation of the acid-base properties such as $\mathrm{pH}$ and $\mathrm{pCO}_{2}$.

In contrast, organic-matter mineralization taking place at anoxic conditions in the Baltic Sea deep basins causes changes in the acid-base system which are specific for marine systems with a pelagic redoxcline. Anoxic mineralization of organic matter generates large amounts of alkalinity by the formation of sulfide ions and the release of ammonia. This reduces the increase in the $\mathrm{pCO}_{2}$ in the deep water and stabilizes the $\mathrm{pH}$ at a value close to 7 . Although these processes are reversed upon re-oxidation during a deep-water renewal event and do not affect the acid-base system of the Baltic Sea as a whole, they do influence the deep-water redox chemistry, which is partly controlled by the $\mathrm{pH}$. On the other hand, the existence of a pelagic redoxcline has other furtherreaching importance. It is the medium for intense denitrification, which increases the alkalinity not only locally but may affect the alkalinity budget of the entire Baltic Sea Proper (Gustafsson et al., 2014b). 
Our compilation of the major features of the Baltic Sea acid-base system indicates that an exact quantitative treatment of its properties is difficult to achieve. This refers to both the biogeochemical modelling and the interpretation of measured alkalinity in terms of the calculation of individual alkalinity contributions. An example is the calculation of the carbonate alkalinity that is necessary for the full characterization of the $\mathrm{CO}_{2}$ system based on measurements of alkalinity together with another variable. This requires knowledge of the dissociation constants and the determination of the total concentrations of the individual compounds with acid-base properties. Regarding inorganic alkalinity contributions, it may be realistic to obtain this information. But in view of our limited knowledge concerning the composition of the dissolved organic matter, it is currently impossible to specify and characterize the contributions of individual organic acid-base compounds to the alkalinity. Hence we conclude that this is one of the greatest challenges for more adequate comprehensive physico-chemical characterization of the acid-base system in the Baltic Sea and likely in other coastal seas. Another important limitation, especially for the biogeochemical modelling, is also an insufficient knowledge of the short- and long-term development of alkalinity loads from land caused by processes occurring in the catchment.

Competing interests. The authors declare that they have no conflict of interest.

Acknowledgements. The study was completed thanks to funding provided by the National Science Centre, Poland, grant nos. 2015/19/B/ST10/02120 and 2014/13/D/ST10/01885. Significant financial support was provided also by BONUS and the Polish National Centre for Research and Development - sponsors of BONUS PINBAL project (grant no. BONUS-INNO-2012-03/2014). The contribution of B. Schneider to this study was supported by the Foundation for Polish Science within the Alexander von Humboldt Polish Honorary Research Scholarship. This study comprises a part of the Baltic Earth - Earth System Science for the Baltic Sea Region. We thank both anonymous reviewers for insightful and constructive comments and suggestions.

Edited by: Marcus Reckermann

Reviewed by: two anonymous referees

\section{References}

Bates, N. R., Astor, Y. M., Church, M. J., Currie, K., Dore, J. E., Gonzalez-Davila, M., Lorenzoni, L., Muller-Karger, F. E., Olafsson, J., and Santana-Casiano, J. M.: A time-series view of changing surface ocean chemistry due to ocean uptake of anthropogenic $\mathrm{CO}_{2}$ and ocean acidification, Oceanography, 27, 126$141,2014$.
Beldowski, J., Loeffler, A., Schneider, B., and Joensuu, L.: Distribution and biogeochemical control of total $\mathrm{CO}_{2}$ and total alkalinity in the Baltic Sea, J. Marine Syst., 81, 252-259, 2010.

Brenner, H., Braeckman, U., Le Guitton, M., and Meysman, F. J. R.: The impact of sedimentary alkalinity release on the water column $\mathrm{CO}_{2}$ system in the North Sea, Biogeosciences, 13, 841863, https://doi.org/10.5194/bg-13-841-2016, 2016.

Brewer, P. G. and Goldman, J. C.: Alkalinity changes generated by phytoplankton growth, Limnol. Oceanogr., 21, 108-117, 1976.

Buch, K.: Kolsyrejamvikten i Baltiska Havet, Fennia, 68, 5, 29-81, 1945.

Cai, W. J., Wang, Y. C., and Hodson, R. E.: Acid-base properties of dissolved organic matter in the estuarine waters of Georgia, USA, Geochim. Cosmochim. Ac., 62, 473-483, 1998.

Caldeira, K. and Wickett, M. E.: Anthropogenic carbon and ocean pH, Nature, 425, 365-365, 2003.

Carlson, C. A., Hansell, D. A., Nelson, N. B., Siegel, D. A., Smethie, W. M., Khatiwala, S., Meyers, M. M., and Halewood, E.: Dissolved organic carbon export and subsequent remineralization in the mesopelagic and bathypelagic realms of the North Atlantic basin, Deep-Sea Res. II, 57, 1433-1445, 2010.

Clegg, S. L. and Whitfield, M.: Chemical model of seawater including dissolved ammonia and the stoichiometric dissociation constant of ammonia in estuarine water and seawater from -2 to $40^{\circ} \mathrm{C}$, Geochem. Cosmochim. Ac., 59, 2403-2421, 1995.

DelValls, T. A. and Dickson, A. G.: The $\mathrm{pH}$ of buffers based on 2amino-2-hydroxymethyl-1,3-propanediol ('tris') in synthetic sea water, Deep-Sea Res. Part I, 45, 1541-1554, 1998.

Dickson, A. G.: An exact definition of total alkalinity and a procedure for the estimation of alkalinity and total inorganic carbon from titration data, Deep-Sea Res. I, 28, 609-623, 1981.

Dickson, A. G.: pH scales and proton-transfer reactions in saline media such as sea water, Geochim. Cosmochim. Ac., 48, 22992308, 1984.

Dickson, A. G., Sabine, C. L., and Christian, J. R.: Guide to best practices for ocean $\mathrm{CO}_{2}$ measurements, PICES Special Publication 3, North Pacific Marine Science Organization, Sidney, British Columbia, 191 pp., 2007.

Edman, M. and Omstedt, A.: Modeling the dissolved $\mathrm{CO}_{2}$ system in the redox environment of the Baltic Sea, Limnol. Oceanogr., 58, 74-92, https://doi.org/10.4319/lo.2013.58.1.0074, 2013.

Emerson, S. R. and Hedges, J. I. (Eds.): Chemical Oceanography and the Marine Carbon Cycle, Cambridge University Press, Cambridge, 470 pp., 2008.

Gustafsson, E., Deutsch, B., Gustafsson, B. G., Humborg, C., and Morth, C. M.: Carbon cycling in the Baltic Sea - the fate of allochthonous organic carbon and its impact on air-sea $\mathrm{CO}_{2}$ exchange, J. Marine Syst., 129, 289-302, 2014a.

Gustafsson, E., Wällstedt, T., Humborg, Ch., Mörth, C. M., and Gustafsson, B. G.: External total alkalinity loads versus internal generation: The influence of nonriverine alkalinity sources in the Baltic Sea, Global Biogeochem. Cy., 28, 1358-1370, 2014 b.

Gustafsson, E., Omstedt, A., and Gustafsson, B. G.: The air-water $\mathrm{CO}_{2}$ exchange of a coastal sea-A sensitivity study on factors that influence the absorption and outgassing of $\mathrm{CO}_{2}$ in the Baltic Sea, J. Geophys. Res.-Ocean., 120, 5342-5357, 2015.

Hammer, K., Schneider, B., Kuliński, K., and Schulz-Bull, D. E.: Precision and accuracy of spectrophotometric $\mathrm{pH}$ measurements 
at environmental conditions in the Baltic Sea, Estuar. Coast. Shelf S., 146, 24-32, 2014.

Hammer, K., Schneider, B., Kuliński, K., and Schulz-Bull, D.: Acid-base properties of Baltic Sea dissolved organic matter, J. Marine Syst., 173, 114-121, 2017.

HELCOM: Eutrophication in the Baltic Sea, Balt, Sea Environ. Proc., 115 pp., 2009.

Hernandez-Ayon, J. M., Zirino, A., Dickson, A. G., Camiro-Vargas, T., and Valenzuela-Espinoza, E.: Estimating the contribution of organic bases from microalgae to the titration alkalinity in coastal seawaters, Limnol. Oceanogr.-Meth., 5, 225-232, 2007.

Hjalmarsson, S., Wesslander, K., Anderson, L. G., Omstedt, A., Perttila, M., and Mintrop, L.: Distribution, long-term development and mass balance calculation of total alkalinity in the Baltic Sea, Cont. Shelf Res., 28, 593-601, 2008.

Hoikkala, L., Kortelainen, P., Soinne, H., and Kuosa, H.: Dissolved organic matter in the Baltic Sea, J. Marine Syst., 142, 47-61, 2015.

Hunt, C. W., Salisbury, J. E., and Vandemark, D.: Contribution of non-carbonate anions to total alkalinity and overestimation of $\mathrm{pCO}_{2}$ in New England and New Brunswick rivers, Biogeosciences, 8, 3069-3076, https://doi.org/10.5194/bg-8-30692011, 2011.

Johansson, O. and Wedborg, M.: The Ammonia-Ammonium equilibrium in sea water at temperatures between $5-25^{\circ} \mathrm{C}$, J. Solution Chem., 9, 37-44, 1980.

Koeve, W. and Oschlies, A.: Potential impact of DOM accumulation on $\mathrm{fCO}_{2}$ and carbonate ion computations in ocean acidification experiments, Biogeosciences, 9, 3787-3798, https://doi.org/10.5194/bg-9-3787-2012, 2012.

Kremling, K.: Untersuchungen über die chemische Zusammensetzung des Meerwassers aus der Ostsee II, Frühjahr 1967-Frühjahr 1968, Kiel Meeresforsch., 26, 1-20, 1970.

Kremling, K.: Untersuchungen über die chemische Zusammensetzung des Meerwassers aus der Ostsee III, Frühjahr 1969-Herbst 1970, Kiel Meeresforsch., 27, 99-118, 1972.

Krumins, V., Gehlen, M., Arndt, S., Van Cappellen, P., and Regnier, P.: Dissolved inorganic carbon and alkalinity fluxes from coastal marine sediments: model estimates for different shelf environments and sensitivity to global change, Biogeosciences, 10, 371-398, https://doi.org/10.5194/bg-10-371-2013, 2013.

Kuliński, K. and Pempkowiak, J.: The carbon budget of the Baltic Sea, Biogeosciences, 8, 3219-3230, https://doi.org/10.5194/bg8-3219-2011, 2011.

Kuliński, K., She, J., and Pempkowiak, J.: Short and medium term dynamics of the carbon exchange between the Baltic Sea and the North Sea, Cont. Shelf Res., 31, 1611-1619, 2011.

Kuliński, K., Schneider, B., Hammer, K., Machulik, U., and SchulzBull, D.: The influence of dissolved organic matter on the acidbase system of the Baltic Sea, J. Marine Syst., 132, 106-115, 2014.

Kuliński, K., Hammer, K., Schneider, B., and Schulz-Bull, D.: Remineralization of terrestrial dissolved organic carbon in the Baltic Sea, Mar. Chem., 181, 10-17, 2016.

Kuznetsov, I., Neumann, T., Schneider, B., and Yakushev, E.: Processes regulating $\mathrm{pCO}_{2}$ in the surface waters of the central eastern Gotland Sea: A model study, Oceanologia, 53, 745-770, 2011.
Kuznetsov, I. and Neumann T.: Simulation of carbon dynamics in the Baltic Sea with a 3D model, J. Marine Syst., 111-112, 167174, 2013.

Lass, H.-U. and Matthäus, W.: General Oceanography of the Baltic Sea, in: State and Evolution of the Baltic Sea, 1952-2005: Detailed 50-Year Survey of Meteorology and Climate, Physics, Chemistry, Biology and Marine Environment, edited by: Feistel, R., Nausch, G., and Wasmund, N., John Wiley \& Sons, Inc., USA, 5-43, 2008.

Le Quéré, C., Andrew, R. M., Canadell, J. G., Sitch, S., Korsbakken, J. I., Peters, G. P., Manning, A. C., Boden, T. A., Tans, P. P., Houghton, R. A., Keeling, R. F., Alin, S., Andrews, O. D., Anthoni, P., Barbero, L., Bopp, L., Chevallier, F., Chini, L. P., Ciais, P., Currie, K., Delire, Ch., Doney, S. C., Friedlingstein, P., Gkritzalis, T., Harris, I., Hauck, J., Haverd, V., Hoppema, M., Goldewijk, K. K., Jain, A. K., Kato, E., Körtzinger, A., Landschützer, P., Lefèvre, N., Lenton, A., Lienert, S., Lombardozzi, D., Melton, J. R., Metzl, N., Millero, F., Monteiro, P. M. S., Munro, D. R., Nabel, J. E. M. S., Nakaoka, S., O’Brien, K., Olsen, A., Omar, A. M., Ono, T., Pierrot, D., Poulter, B., Rödenbeck, Ch., Salisbury, J., Schuster, U., Schwinger, J., Séférian, R., Skjelvan, I., Stocker, B. D., Sutton, A. J., Takahashi, T., Tian, H., Tilbrook, B., van der Laan-Luijkx, I. T., van der Werf, G. R., Viovy, N., Walker, A. P., Wiltshire, A. J., and Zaehle S.: Global Carbon Budget 2016, Earth Syst. Sci. Data, 8, 605-649, https://doi.org/10.5194/essd-8-605-2016, 2016.

Lee, K., Kim, T. W., Byrne, R. H., Millero, F. J., Feely, R. A., and Liu, Y. M.: The universal ratio of boron to chlorinity for the North Pacific and North Atlantic oceans, Geochim. Cosmochim. Ac., 74, 1801-1811, 2010.

Lukawska-Matuszewska, K.: Contribution of non-carbonate inorganic and organic alkalinity to total measured alkalinity in pore waters in marine sediments (Gulf of Gdansk, S-E Baltic Sea), Mar. Chem., 186, 211-220, 2016.

Millero, F. J.: Carbonate constants for estuarine waters, Mar. Freshwater Res., 61, 139-142, 2010.

Millero, F. J., Plese, T., and Fernandez, M.: The dissociation of hydrogen sulfide in seawater (Note), Limnol. Oceanogr., 33, 269$274,1988$.

Millero, F. J., Graham, T. B., Huang, F., Bustos-Serrano, H., and Pierrot, L. D.: Dissociation constants of carbonic acid in seawater as a function of salinity and temperature, Mar. Chem., 100, 80 94, 2006

Mosley, L. M., Husheer, S. L. G., and Hunter, K. A., Spectrophotometric $\mathrm{pH}$ measurement in estuaries using thymol blue and $\mathrm{m}$ cresol purple, Mar. Chem., 91, 175-186, 2004.

MSFD: Directive 2008/56/EC of the European Parliament and of the Council (Marine Strategy Framework Directive), EUR-Lex - 32008L0056 - EN, available at: http://data.europa.eu/eli/dir/ 2008/56/oj, 2008.

Müller, J. D., Schneider, B., and Rehder, G.: Long-term alkalinity trends in the Baltic Sea and their implications for $\mathrm{CO}_{2}$-induced acidification, Limnol. Oceanogr., 61, 1984-2002, 2016.

Nausch, G., Nehring, D., and Nagel, K.: Nutrients Concentrations, Trends and Their Relation to Eutrophication, in: State and Evolution of the Baltic Sea, 1952-2005: Detailed 50-Year Survey of Meteorology and Climate, Physics, Chemistry, Biology, and Marine Environment, edited by: Feistel, R., Nausch, G., and Wasmund, N., John Wiley \& Sons, Inc., USA, 2008. 
Nebbioso, A. and Piccolo, A.: Molecular characterization of dissolved organic matter (DOM): a critical review, Anal. Bioanal. Chem, 405, 109-124, 2013.

Omstedt, A., Gustafsson, E., and Wesslander, K.: Modelling the uptake and release of carbon dioxide in the Baltic Sea surface water, Cont. Shelf Res., 29, 870-885, 2009.

Omstedt, A., Edman, M., Anderson, L. G., and Laudon H.: Factors influencing the acid-base $(\mathrm{pH})$ balance in the Baltic Sea: a sensitivity analysis, Tellus B, 62, 280-295, 2010.

Omstedt, A., Edman, M., Claremar, B., Frodin, P., Gustafsson, E., Humborg, C., Hagg, H., Morth, M., Rutgersson, A., Schurgers, G., Smith, B., Wallstedt T., and Yurova, A.: Future changes in the Baltic Sea acid-base $(\mathrm{pH})$ and oxygen balances, Tellus B, 64, 19586, https://doi.org/10.3402/tellusb.v64i0.19586, 2012.

Omstedt, A., Edman, M., Claremar, B., Rutgersson, A., Modelling the contributions to marine acidification from deposited $\mathrm{SO}_{x}$, $\mathrm{NO}_{x}$, and $\mathrm{NH}_{x}$ in the Baltic Sea: Past and present situations, Cont. Shelf Res., 111, 234-249, 2015.

Orr, J. C., Epitalon, J.-M., and Gattuso, J.-P.: Comparison of ten packages that compute ocean carbonate chemistry, Biogeosciences, 12, 1483-1510, https://doi.org/10.5194/bg-12-14832015, 2015.

Redfield, A. C., Ketchum, B. H., and Richards, F. A.: The influence of organisms on the composition of sea water, in: The Sea, edited by: Hill, M. N., Interscience, New York, USA, 26-77, 1963.

Reed, D. C., Gustafsson, B. G., and Slomp, C. P.: Shelf-to-basin iron shuttling enhances vivianite formation in deep Baltic Sea sediments, Earth Planet. Sc. Lett., 434, 241-251, 2016.

Riebesell, U., Fabry, V. J., Hansson, L., and Gattuso J.-P.: Guide to best practices for ocean acidification research and data reporting, 260 pp., Luxembourg, Publications Office of the European Union, 2010.

Roy, R. N., Roy, L. N., Vogel, K. M., Porter-Moore, C., Pearson, T., Good, C. E., Millero, F. J., and Campbell, D. M.: The dissociation constants of carbonic acid in seawater at salinities 5 to 45 and temperatures 0 to $45^{\circ} \mathrm{C}$, Mar. Chem., 44, 249-267, 1993.

Schneider, B.: The $\mathrm{CO}_{2}$ system of the Baltic Sea : biogeochemical control and impact of anthropogenic $\mathrm{CO}_{2}$, in: Global change and Baltic coastal zones, edited by Schernewski, G., Hofstede, J., and Neumann, T., Dordrecht: Springer Science+Business Media (Coastal research library), 33-49, 2011.

Schneider, B., Gülzow, W., Sadkowiak, B., and Rehder, G.: Detecting sinks and sources of $\mathrm{CO}_{2}$ and $\mathrm{CH}_{4}$ by ferrybox-based measurements in the Baltic Sea: Three case studies, J. Marine Syst., 140, 13-25, 2014.
Schneider, B., Eilola, K., Lukkari, K., Muller-Karulis, B., and Neumann, T.: Environmental Imapacts - Marine Biogeochemistry, in: BACC II Author Team, Second Assessment of Climate Change for the Baltic Sea Basin, Springer, Heidelberg, 337-361, 2015.

Schulz, H. D. and Zabel, M.: Marine geochemistry, Springer-Verlag Berlin Heidelberg, 574 pp., 2006.

Szymczycha, B., Maciejewska, A., Winogradow, A., and Pempkowiak, J.: Could submarine groundwater discharge be a significant carbon source to the southern Baltic Sea?, Oceanologia, 56, 327-347, 2014.

Thomas, H., Schiettecatte, L.-S., Suykens, K., Koné, Y. J. M., Shadwick, E. H., Prowe, A. E. F., Bozec, Y., de Baar, H. J. W., and Borges, A. V.: Enhanced ocean carbon storage from anaerobic alkalinity generation in coastal sediments, Biogeosciences, 6, 267274, https://doi.org/10.5194/bg-6-267-2009, 2009.

Tyrrell, T., Schneider, B., Charalampopoulou, A., and Riebesel, U.: Coccolithophores and calcite saturation state in the Baltic and Black Seas, Biogeosciences, 5, 485-494, https://doi.org/10.5194/bg-5-485-2008, 2008.

Ulfsbo, A., Hulth S., and Anderson, L. G.: pH and biogeochemical processes in the Gotland Basin of the Baltic Sea, Mar. Chem., 127, 20-30, 2011.

Ulfsbo, A., Kuliński, K., Anderson, L. G., and Turner, D. R.: Modelling organic alkalinity in the Baltic Sea using a Humic-Pitzer approach, Mar. Chem., 168, 18-26, 2015.

Uppström, L. R.: The boron/chlorinity ratio of deep-sea water from the Pacific Ocean, Deep-Sea Res., 21, 161-162, 1974.

Weiss, R. F.: Carbon dioxide in water and seawater: the solubility of a non-ideal gas, Mar. Chem., 2, 203-215, 1974.

Winsor, P., Rodhe, J., and Omstedt, A.: Baltic Sea ocean climate: an analysis of $100 \mathrm{yr}$ of hydrographic data with focus on the freshwater budget, Clim. Res., 18, 5-15, 2001.

Wolf-Gladrow, D. A., Zeebe, R. E., Klaas, C., Körtzinger, A., and Dickson, A. G.: Total alkalinity: The explicit conservative expression and its application to biogeochemical processes, Mar. Chem., 106, 287-300, 2007.

Zeebe, R. E.: History of Seawater Carbonate Chemistry, Atmospheric $\mathrm{CO}_{2}$, and Ocean Acidification, Annu. Rev. Earth Pl. Sc., 40, 141-165, 2012. 